\title{
Morphometric Study of Dried Cervical Vertebrae
}

\author{
Estudio Morfométrico de Vértebras Cervicales Secas
}

Sema Polat; Pınar Göker; Ahmet Hilmi Yücel \& Memduha Gülhal Bozkır

POLAT, S.; GÖKER, P.; YÜCEL, A. H. \& BOZKIR, M. G. Morphometric study of dry cervical vertebrae. Int. J. Morphol., 37(3):845$851,2019$.

SUMMARY: The aim of this study was to emphasize the clinical importance of morphometry and the surgical parameters of the cervical vertebrae. The present study was carried out on ninety six adult dry cervical vertebrae (C3-C7, 96) of unknown gender of Turkish population. The various dimensions of the cervical vertebrae (from C3 to C7) were measured with using a digital caliper accurate to $0.01 \mathrm{~mm}$. Linear parameters including vertebral body anteroposterior width $(14.03 \mathrm{~mm})$, vertebral body transverse width (24.45 mm); vertebral body height $(10.64 \mathrm{~mm})$; pedicle length $(\mathrm{R}: 5.65 \pm 1.91 \mathrm{~mm}, \mathrm{~L}: 5.65 \pm 1.76 \mathrm{~mm})$; pedicle width $(\mathrm{R}: 3.72 \mathrm{~mm}, \mathrm{~L}: 3.61 \mathrm{~mm})$; lamina height (R:9.87 mm, L:9.86 mm); lamina transverse length (R:13.41 mm, L:13.49 mm); superior articular process anteroposterior width (R:7.26 mm, L:7.46 mm); superior articular process transverse diameter (R: $9.87 \mathrm{~mm}, \mathrm{~L}: 9.58 \mathrm{~mm})$; superior articular process height (R:16.41 mm, L:16.08 mm); inferior articular process anteroposterior width (R: $7.67 \mathrm{~mm}, \mathrm{~L}: 7.44 \mathrm{~mm})$; inferior articular process transverse diameter (R: $10.32 \mathrm{~mm}, \mathrm{~L}: 10.09 \mathrm{~mm})$; inferior articular process height (R:12.72 mm, L:12.67 mm); spinous process length (17.91 mm); uncinate process width (R:4.37 mm, L:3.78 mm); uncinate process height (R:4.58 mm, L:3.93 mm); uncinate process length (R:9.28 $\mathrm{mm}$, L:9.12 $\mathrm{mm})$; vertebral foramen anteroposterior width $(13.85 \mathrm{~mm})$; vertebral foramen transverse diameter $(20.88 \mathrm{~mm})$; foramen transversarium anteroposterior width (R:4.23 mm, L:4.28 mm); foramen transversarium transverse diameter (R:4.78 mm, L:4.95 mm) were measured. Additionally, the distance of the apex of the uncinate process to foramen transversarium (R:2.91 $\mathrm{mm}, \mathrm{L}: 2.70 \mathrm{~mm})$, and the distance of the apex of the uncinate process to intervertebral foramen (R: $5.77 \mathrm{~mm}, \mathrm{~L}: 5.66 \mathrm{~mm})$ were also calculated. There were found significant differences between two sides in the uncinate process width and height, and distance between uncinate process and foramen transversarium. Present measurements suggest that parameters relevant cervical vertebrae can be used as reference and anatomical landmark for evaluating pathologic changes and minimizing complications in the cervical spine.

KEY WORDS: Cervical vertebrae, uncinate process, foramen transversarium, morphometry.

\section{INTRODUCTION}

Vertebral column formed of thirty three (33) vertebrae, is divided into five groups based on morphology and location. These are seven (7) cervical vertebrae, twelve (12) thoracic vertebrae, five (5) lumbar vertebrae, five (5) sacral vertebrae and four (4) coccygeal vertebrae (Gupta et al., 2017). A characteristic cervical vertebrae consists of vertebral body, pedicle, lamina, transverse process, spinous process, and superior and inferior articular process (Drake et al., 2010). A foramen in transverse process is an important feature of the cervical vertebrae. It passes through vertebral artery, vertebral veins, and sympathetic nerves. Foramen transversarium may show the variation about shape, size, and be unilateral, bilateral, multiple or absent (Murlimanju et al., 2011; Gupta et al.). Furthermore, the existence of the accessory foramen transversarium may lead to vertebral artery compression. Vertebral vascular insufficiency may results in problems such as headache, migraine and fainting.
Cervical vertebrae are entitled as typical (third, fourth, fifth and sixth) and atypical (first, second and seventh) cervical vertebrae (Gupta et al.).

Many studies of cervical vertebrae dimensions have been carried out until today. (Abuzayed et al., 2010; Bazaldúa Cruz et al., 2011; Murlimanju et al.; Gupta et al.; Kocabiyik et al., 2017). On the other hand, the morphometric measurements in vertebrae can change between the races (Abuzayed et al.; Bazaldúa Cruz et al.; Mahto \& Omar, 2015; Desdicioglu et al., 2017; Prabavathy et al., 2017). Interestingly, the knowledge of cervical vertebrae morphology is significant for avoid damage to the vertebral artery, spinal medulla, or nerve roots during fixation process (Bazaldúa Cruz et al.). Rathke has defined the uncinate process (UP) as a bony protuberance in previous century. UP localization extends up to the third cervical vertebra, 
and down to the second thoracic vertebra, anteriorly and posteriorly respectively. They are mostly found between segments third cervical vertebrae and seventh cervical vertebrae. In addition, uncinate processes which are extended from lateral or posterolateral side of cervical vertebral body, are defined as bony protuberances, protuberentia, prominentia, etc. (Kocabiyik et al.). Although there have been made a large number of studies on cervical vertebrae in the literature, it has been noted that there are few studies including detailed morphometry of cervical vertebrae conducted in the Turkish population.

The current study was carried out to determine significance in terms of clinical of the anatomical structures of cervical vertebrae in Turkish population

\section{MATERIAL AND METHOD}

This study was based on observations of ninety six (96) cervical vertebrae. The data were collected from Anatomy Laboratory of Cukurova University Faculty of Medicine. The following parameters were measured on each cervical vertebrae with an electronic digital caliper accurate to $0.01 \mathrm{~mm}$ from $\mathrm{C} 3$ to $\mathrm{C} 7$ vertebrae. Measurements of the cervical vertebrae shown in Table I were as follows:

Vertebral body anteroposterior width: Distance between anterior and posterior surfaces of the body at the medial line (Bazaldúa Cruz et al.; Mahto \& Omar).

Vertebral body transverse width: Distance between two lateral surfaces of the vertebral body (Bazaldúa Cruz et al.; Mahto \& Omar).

Vertebral body height: Distance between superior and inferior margins of the vertebral body at the midline anteriorly (Bazaldúa Cruz et al.; Mahto \& Omar).

Pedicle length: The distance between anterior margin of the superior articular facet and posterior margin of the vertebral body (Bazaldúa Cruz et al.; Devaraj et al., 2017).

Pedicle width: The distance between medial and lateral margins of pedicle (Bazaldúa Cruz et al.; Devaraj et al.).

Lamina height: The distance between superior and inferior margins (Bazaldúa Cruz et al.; Prabavathy et al.).

Lamina transverse length: The distance between anterior margin of the spinous process and lateral margin of the superior articular process (Bazaldúa Cruz et al.)
Superior articular process height: The distance from inferior margin to superior top of the process (Bazaldúa Cruz et al.).

Superior articular process transverse diameter: The transverse distance between two lateral margin of the process (Bazaldúa Cruz et al.).

Superior articular process anteroposterior width: The distance between anterior and posterior margins of the process (Bazaldúa Cruz et al.).

Inferior articular process height: The distance from superior margin to the inferior top of the process (Bazaldúa Cruz et al.).

Inferior articular process transverse diameter: The transverse distance between two margins of the process (Bazaldúa Cruz et al.).

Inferior articular process anteroposterior width: The distance between anterior and posterior margins of the process (Bazaldúa Cruz et al.).

Spinous process length: The distance from the superior margin to the tip of the spinous process (Bazaldúa Cruz et al.).

The uncinate process width: The distance between lateral and medial margins of the cervical uncinate process at process base (Bozbug a et al., 1999; Lee et al., 2012; Kocabiyik et al.).

The uncinate process length: The length between anterior and posterior parts of the uncinate process (Bozbug a $\mathrm{et}$ al.; Lee et al., 2012; Kocabiyik et al.).

The uncinate process height: Distance between the tip of the uncinate process and the base of the uncinate process (Bozbuga et al.; Lee et al., 2012; Kocabiyik et al.).

The distance of the apex of the uncinate process to intervertebral foramen were measured (Kocabiyik et al.).

The distance of the apex of the uncinate process to foramen transversarium were measured (Kocabiyik et al.).

Vertebral foramen anteroposterior width: The maximum anteroposterior length of vertebral canal or foramen vertebrae at the midline (Sengül \& Kadıglu, 2006; Gosavi \& Vatsalaswamy, 2012).

Vertebral foramen transverse diameter: The maximum 
distance between two lateral limits of vertebral foramen at the medial line (Sengül \& Kadioglu; Gosavi \& Vatsalaswamy).

Foramen transversarium anteroposterior width: The maximum anteroposterior diameter of foramen transversarium (Gosavi \& Vatsalaswamy; Yesender et al., 2017; Molinet Guerra et al., 2017).

Foramen transversarium transverse diameter: The maximum transverse diameter of foramen transversarium or distance between two lateral margins (Gosavi \& Vatsalaswamy; Yesender et al.; Molinet Guerra et al.).

The SPSS 21.0 program was used for statistical analysis of the measurement results. From these measurements, means, standard deviations (SD), and minimum (min.) and maximum (max.) values were calculated. Also, Paired Samples T test were used to determine whether there was a significance difference or not in comparison of measurements in right and left sides. $\mathrm{p}<0.05$ was considered as statistically significant.

\section{RESULTS}

The minimum (min.), maximum (max.), mean and standard deviations (SD) values of the measurements from cervical vertebrae (C3-C7) were shown in Table I respectively. The following means of parameters relevant cervical vertebrae were observed; vertebral body anteroposterior width $(14.03 \mathrm{~mm})$, vertebral body transverse width $(24.45 \mathrm{~mm})$; vertebral body height $(10.64 \mathrm{~mm})$; pedicle length (R:5.65 $\pm 1.91 \mathrm{~mm}, \mathrm{~L}: 5.65 \pm 1.76 \mathrm{~mm})$; pedicle width (R:3.72 mm, L:3.61 mm); lamina height (R:9.87 mm, L:9.86 $\mathrm{mm})$; lamina transverse length (R:13.41 mm, L:13.49 mm); superior articular process anteroposterior width $(\mathrm{R}: 7.26 \mathrm{~mm}$, $\mathrm{L}: 7.46 \mathrm{~mm}$ ); superior articular process transverse diameter (R: $9.87 \mathrm{~mm}, \mathrm{~L}: 9.58 \mathrm{~mm}$ ); superior articular process height (R:16.41 mm, L:16.08 mm); inferior articular process anteroposterior width (R: $7.67 \mathrm{~mm}, \mathrm{~L}: 7.44 \mathrm{~mm}$ ); inferior articular process transverse diameter (R: $10.32 \mathrm{~mm}, \mathrm{~L}: 10.09$ $\mathrm{mm})$; inferior articular process height ( $\mathrm{R}: 12.72 \mathrm{~mm}, \mathrm{~L}: 12.67$ $\mathrm{mm})$; spinous process length $(17.91 \mathrm{~mm})$; uncinate process width (R:4.37 mm, L:3.78 mm); uncinate process height (R:4.58 mm, L:3.93 mm); uncinate process length (R:9.28 $\mathrm{mm}, \mathrm{L}: 9.12 \mathrm{~mm})$; vertebral foramen anteroposterior width (13.85 mm); vertebral foramen transverse diameter (20.88 $\mathrm{mm}$ ); foramen transversarium anteroposterior width (R:4.23 $\mathrm{mm}, \mathrm{L}: 4.28 \mathrm{~mm})$; foramen transversarium transverse diameter (R:4.78 mm, L:4.95 mm); the distance of the apex of the uncinate process to foramen transversarium (R:2.91 $\mathrm{mm}, \mathrm{L}: 2.70 \mathrm{~mm}$ ), and the distance of the apex of the uncinate process to intervertebral foramen (R: $5.77 \mathrm{~mm}$, L:5.66 mm). However, in assessment of the cervical vertebrae (from C3 to $\mathrm{C} 7$ ) measurements in both sides, there were no found significant difference in some values such as pedicle length $(\mathrm{p}=1.000)$, pedicle width $(\mathrm{p}=0.340)$, superior articular process anteroposterior width $(\mathrm{p}=0.207)$, superior articular process transverse width $(\mathrm{p}=0.144)$, superior articular process height $(\mathrm{p}=0.162)$, inferior articular process anteroposterior width $(\mathrm{p}=0.254)$, inferior articular process transverse width $(\mathrm{p}=0.361)$, inferior articular process height $(\mathrm{p}=0.782)$, lamina height $(p=0.930)$, lamina length $(p=0.578)$, uncinate process length $(\mathrm{p}=0.265)$, foramen transversarium anteroposterior $(\mathrm{p}=0.719)$ and transverse width $(\mathrm{p}=0.225)$, bilateral foramen transversarium anteroposterior $(\mathrm{p}=0.843)$ and transverse width $(\mathrm{p}=0.453)$, and distance between uncinate process and intervertebral foramen $(\mathrm{p}=0.454)$. There were significant difference values of uncinate process width and height, and distance between uncinate process and foramen transversarium $(\mathrm{p}<0.05)$.

\section{DISCUSSION}

Although the basic characteristics of the vertebrae were similiar, the features of the vertebrae vary in size and different due to region, race, genetic and gender parameters (Mahto \& Omar; Desdicioglu et al.; Prabavathy et al.). Also, the success in cervical vertebrae surgery involves the detailed anatomical knowledge for selection and installment of proper screw, plate or surgical instruments (Mahto \& Omar; Rao et al., 2016). The present study provides detailed morphometric information of dry typical cervical vertebrae in Turkish population.

Uncinate process (UP) lies from vertebral body posterior part and it is defined as important bony protuberance in head and neck motions. Also, the variations of UP provide the surgeon to be more effective in treating the pathological lesion and complications. It is known that UP are commonly located at $\mathrm{C} 3$ and $\mathrm{C} 7$ and this structure is one of the characteristic of cervical vertebrae (Bozbuga et al.; Kocabiyik et al.). The connection or relation of the UP to inferior side of vertebrae constitudes the uncovertebral joints. Uncovertebral joints plays an important role in cervical spine stability. If degeneration develops in uncovertebral joints, the compressive effect of uncinate osteophytes may arise and end up with nerve root compression in intervertebral foramen, or vertebral artery compression, or cervical spondylotic radiculopathy. Therefore, some symptoms including pain, paraesthesia, muscle weakness, reflex decay or vertebral and basilar failures are seen. UP or uncovertebral 
Table I. Cervical vertebrae measurements.

\begin{tabular}{|c|c|c|c|}
\hline Cervical vertebrae (C3-C7) Measurements (mm) & $\mathrm{N}$ & Min & Max. \\
\hline Vertebral body transverse width & 96 & 17.30 & 32.00 \\
\hline Vertebral body anteroposterior width & 96 & 10.50 & 20.00 \\
\hline Vertebral body height & 96 & 3.50 & 20.00 \\
\hline \multirow[t]{2}{*}{ Pedicle length } & $\mathrm{R}(96)$ & 1.50 & 11.00 \\
\hline & $\mathrm{L}(96)$ & 2.00 & 10.50 \\
\hline \multirow[t]{2}{*}{ Pedicle width } & $\mathrm{R}(96)$ & 1.50 & 8.50 \\
\hline & $\mathrm{L}(96)$ & 1.00 & 9.50 \\
\hline \multirow[t]{2}{*}{ Superior articular process anteroposterior width } & $\mathrm{R}(96)$ & 2.50 & 13.50 \\
\hline & $\mathrm{L}(96)$ & 3.50 & 12.00 \\
\hline \multirow[t]{2}{*}{ Superior articular process transverse diameter } & $\mathrm{R}(96)$ & 5.50 & 15.00 \\
\hline & $\mathrm{L}(96)$ & 5.00 & 15.00 \\
\hline \multirow[t]{2}{*}{ Superior articular process height } & $\mathrm{R}(96)$ & 7.50 & 23.50 \\
\hline & $\mathrm{L}(96)$ & 8.00 & 23.00 \\
\hline \multirow[t]{2}{*}{ Inferior articular process anteroposter ior width } & $\mathrm{R}(96)$ & 3.50 & 13.00 \\
\hline & $\mathrm{L}(96)$ & 3.50 & 16.00 \\
\hline \multirow[t]{2}{*}{ Inferior articular process transverse width } & $\mathrm{R}(96)$ & 5.50 & 17.00 \\
\hline & $\mathrm{L}(96)$ & 6.00 & 17.00 \\
\hline \multirow[t]{2}{*}{ Inferior articular process height } & $\mathrm{R}(96)$ & 5.00 & 21.00 \\
\hline & $\mathrm{L}(96)$ & 6.20 & 21.00 \\
\hline Spinous process length & 96 & 5.00 & 37.00 \\
\hline \multirow[t]{2}{*}{ Lamina height } & $\mathrm{R}(96)$ & 5.00 & 21.00 \\
\hline & $\mathrm{L}(96)$ & 4.00 & 20.00 \\
\hline \multirow[t]{2}{*}{ Lamina transverse length } & $\mathrm{R}(96)$ & 3.50 & 20.00 \\
\hline & $\mathrm{L}(96)$ & 3.00 & 20.00 \\
\hline \multirow[t]{2}{*}{ Uncinate process length } & $\mathrm{R}(96)$ & 5.00 & 16.50 \\
\hline & $\mathrm{L}(96)$ & 4.10 & 16.50 \\
\hline \multirow[t]{2}{*}{ Uncinate process height } & $\mathrm{R}(96)$ & 2.00 & 16.00 \\
\hline & $\mathrm{L}(96)$ & 1.00 & 13.50 \\
\hline \multirow[t]{2}{*}{ Uncinate process width } & $\mathrm{R}(96)$ & 1.00 & 14.00 \\
\hline & L (96) & 0.50 & 11.00 \\
\hline Vertebral foramen anteroposterior width & 96 & 9.00 & 19.50 \\
\hline Vertebral foramen transverse diameter & 96 & 15.00 & 29.00 \\
\hline \multirow[t]{2}{*}{ Foramen transversarium anteroposteri or width } & 96 & 1.00 & 7.00 \\
\hline & 96 & 1.50 & 8.00 \\
\hline \multirow[t]{2}{*}{ Foramen transversarium transverse di ameter } & 96 & 1.90 & 9.00 \\
\hline & 96 & 2.00 & 9.00 \\
\hline \multirow[t]{2}{*}{ Distance between uncinate process and foramen transversarium } & 96 & 1.00 & 6.50 \\
\hline & 96 & 1.00 & 7.50 \\
\hline \multirow[t]{2}{*}{ Distance between uncinate process and intervertebral foramen } & 96 & 1.50 & 11.00 \\
\hline & 96 & 1.50 & 9.00 \\
\hline Unilateral accessory transverse foramina anteroposterior width & $\mathrm{R}(7)$ & 0.50 & 1.00 \\
\hline Unilateral accessory transverse foramina transverse diameter & $\mathrm{R}(7)$ & 1.00 & 2.00 \\
\hline Bilateral accessory transverse foramina anteroposterior width & $\mathrm{R}(3)$ & 0.50 & 1.50 \\
\hline Bilateral accessory transverse foramina transverse diameter & $\mathrm{L}(3)$ & 1.50 & 4.00 \\
\hline Bilateral or unilateral accessory transverse foramina presence (-) & $86(-)$ & & \\
\hline \multirow[t]{2}{*}{ Presence of osteophytes } & $16(+)$ & - & - \\
\hline & $80(-)$ & & \\
\hline
\end{tabular}

joints are the point of the injury in head and neck trauma. So, the knowledge of the UP is essential for safe removal of the uncovertebral joint without damaging the spinal cord, nerve roots or vertebral artery (Bozbuga et al.; Kocabiyik et al.). Some studies was reported the average width of the UP should be 4-6 mm for UP's safely resection (Lu et al., 1998; Bozbuga et al.; Park et al., 2015). Kocabiyik et al. declared that the means of the uncinate process width, height and length at the $\mathrm{C} 3-\mathrm{C} 7$ levels ranged from
$4.25 \mathrm{~mm}$ to $5.50 \mathrm{~mm}$; from 6.11 $\mathrm{mm}$ to $7.54 \mathrm{~mm}$; and from 8.50 $\mathrm{mm}$ to $11.46 \mathrm{~mm}$, respectively (Kocabiyik et al.). Moreover, Bozbug a et al. measured UP width (R:4.5 $\mathrm{mm}$ and $6.1 \mathrm{~mm}$ ), (L:4.8 $\mathrm{mm}$ and $6.2 \mathrm{~mm}$ ); the UP height (R:5.1 $\mathrm{mm}$ and $6.1 \mathrm{~mm}$ ), (L:5.2 $\mathrm{mm}$ and $6.2 \mathrm{~mm}$ ); and the UP length (R:11.9 mm and 12.5 $\mathrm{mm}),(\mathrm{L}: 11.8 \mathrm{~mm}$ and $12.4 \mathrm{~mm})$ (Bozbug a et al.). In Koreans, the width, height and length of the UP were found between $5.5 \mathrm{~mm}$ and $6.3 \mathrm{~mm} ; 5.1 \mathrm{~mm}$ and 5.9 $\mathrm{mm}$; and $13.0 \mathrm{~mm}$ and $13.7 \mathrm{~mm}$ in males, respectively. The corresponding values were measured between $5.5 \mathrm{~mm}$ and $6.3 \mathrm{~mm} ; 4.2 \mathrm{~mm}$ and $6.0 \mathrm{~mm}$; and $11.0 \mathrm{~mm}$ and $12.2 \mathrm{~mm}$ in females, respectively between C3 - C7 segments (Lee et al., 2012; Park et al.). In a study of Tubbs et al. (2012) UP height (ranged from $4.8 \mathrm{~mm}$ to 5.1 $\mathrm{mm}$ ); and UP length (ranged from $6 \mathrm{~mm}$ to $8.1 \mathrm{~mm}$ ) were measured. In a study of Americans, the UP height ranged from $5.0 \mathrm{~mm}$ to $6.3 \mathrm{~mm}$ in males, whereas the same value of females were between $4.8 \mathrm{~mm}$ and $5.8 \mathrm{~mm}$, respectively. The UP width and length values of males were found between 5.0 $\mathrm{mm}$ and $6.5 \mathrm{~mm} ; 11.7 \mathrm{~mm}$ and $12.5 \mathrm{~mm}$, respectively whereas the corresponding values of females ranged from $4.6 \mathrm{~mm}$ and $6.1 \mathrm{~mm} ; 11.3 \mathrm{~mm}$ and $12.4 \mathrm{~mm}$, respectively at C3-C7 levels ( $\mathrm{Lu}$ et al.). Our UP width and height results were lower than above studies'findings. However, the width of the UP was close to the ideal value reported by Bozbug a and Lu et al.'s studies. There was a few studies about the distance from UP to FT, and the distance from UP to IVF in literature. The distance from UP to FT is important for decompression of 
artery during cervical spine anterior approach and may provide the useful knowledge to neurosurgeons and other clinicians. In Indian population, the distance from UP to FT was found as $4.14 \mathrm{~mm}$ in right side, $4.42 \mathrm{~mm}$ in left side, respectively (Yesender et al.). In a study consisting of American population the corresponding value was $5.00 \mathrm{~mm}$ in both sides (Sangari et al., 2015). In Turkish population, the same value was reported between $1.38 \mathrm{~mm}$ and 3.16 $\mathrm{mm}$ at $\mathrm{C} 3-\mathrm{C} 7$ levels (Kocabiyik et al.). The corresponding value was found as $2.91 \mathrm{~mm}$ (right) and $2.70 \mathrm{~mm}$ (left) in present study. Moreover, the distance from UP to IVF was reported between $5.56 \mathrm{~mm}$ and $6.56 \mathrm{~mm}$ at $\mathrm{C} 3-\mathrm{C} 7$ levels (Kocabiyik et al.). The same dimension was found as 5.77 $\mathrm{mm}$ and $5.66 \mathrm{~mm}$ in right and left sides in this paper.

The foramen transversarium which is unique to the cervical vertebrae is found on the transverse process. Plexus sympaticus, vertebral artery and vein passes inside (Aydınlıg `lu et al., 2001; Murlimanju et al.; Gujar et al., 2015; Molinet Guerra et al.). FT narrowing is a sign of the vertebrobasilar inadequacy and the formation of trombosus which occurs during head rotation (Yesender et al.). The variations of FT may be occurred due to many reasons such as penetrating injuries, trauma, or vascular compression developped secondary to fractures or luxations and width and path of the vascular elements (Dalgic et al., 2009; Murlimanju et al; Molinet Guerra et al.) and these deformations or variations of FT lead to pathologic conditions or clinical findings by affecting significant arteries and veins during course (Aydınlıg \lu et al.). Moreover, some health problems such as headache, migraine, and fainting attacks or compression of vertebral artery are possible reasons for the foramina transversaria number and size variations (Murlimanju et al.; Molinet Guerra et al.). Also, an absence of foramen transversarium refer absence of the vertebral artery. Additionaly, a narrowing of the foramina shows narrowness of the vessels (Murlimanju et al.). So, to know these variations are beneficial for estimate differences in the pattern of the vertebral artery and vein, or nerves passed inside FT (Aydinlıglu et al., 2001). These variations are significant for physicians, neurosurgeans, and radiologist in the outcome monitoring like computed tomogram or magnetic resonance image scanes (Murlimanju et al.; Molinet Guerra et al.). Because, vertebral and basilar arteries which makes a significant contribution to blood supply for brain and inner ear. Compression or spasm of the vertebral artery may be cause both neurological symptoms and hearing problems (Murlimanju et al.). In studies about foramen transversarium, the means of the anteroposterior and transverse width vary in populations (Murlimanju et al.; Molinet Guerra et al.; Yesender et al.; Ananthi et al., 2019). In studies consisting of Indians, the means of FT transverse diameter and FT anteroposterior width were reported between $5.20 \mathrm{~mm}$ and $6.72 \mathrm{~mm}$ in right, and $5.05 \mathrm{~mm}$ and $6.66 \mathrm{~mm}$ in left; $4.08 \mathrm{~mm}$ and $5.45 \mathrm{~mm}$ in right, and 3.75 $\mathrm{mm}$ and $5.56 \mathrm{~mm}$ in left side, respectively (Yesender et al.; Ananthi et al.). The same values were found $5.69 \mathrm{~mm}$ and $5.87 \mathrm{~mm}$; and $5.17 \mathrm{~mm}$ and $5.13 \mathrm{~mm}$ in right and left side, respectively in Americans (Sangari et al.). In Chilean population, the FT diameter ranged from $4.47 \mathrm{~mm}$ to 6.11 $\mathrm{mm}$ in right side; $4.43 \mathrm{~mm}$ to $5.42 \mathrm{~mm}$ in left side (Molinet Guerra et al.). In our study, the FT transverse diameter (R:4.78 mm, L:4.95 mm) were found lower than Indians and Americans, whereas that dimension was obtained similar to Molinet Guerra et al.'s study. The FT anteroposterior width (R:4.23 mm, L:4.28 mm) in this study was lower than American population.

There are many studies on the vertebral body morphometry in literature (Y1lmazlar et al., 2003; Abuzayed et al.; Bazaldúa Cruz et al.; Mahto \& Omar; Prabavathy et $a l$.). The vertebral body development may be affected some factors including genetic, race, postural or occupational lesions (Mahto \& Omar; Prabavathy et al.). The vertebral body morphometry provides important knowledge for surgeons performing anterior cervical reconstructions or diagnose many clinicinal problems such as stenosis, degenerative disorders (Abuzayed et al.; Bazaldúa Cruz et $a l$.; Prabavathy et al.). Also, the vertebral body anteroposterior diameter was a useful parameter for the anterior fixation of bicortical screws (Bazaldúa Cruz et al.). Researches in different populations, anteroposterior (AP) diameter of vertebral body was declared between $14.02 \mathrm{~mm}$ and $15.79 \mathrm{~mm}$ (Yilmazlar et al., 2003); $14.68 \mathrm{~mm}$ and 17.47 mm (Bazaldúa Cruz et al.); $14.4 \mathrm{~mm}$ and $16.1 \mathrm{~mm}$ in females; $16.00 \mathrm{~mm}$ and $17.80 \mathrm{~mm}$ in males (Lee et al., 2012); $14.70 \mathrm{~mm}$ and $15.6 \mathrm{~mm}$ in females; $16.70 \mathrm{~mm}$ and 17.30 $\mathrm{mm}$ in males (Kwon et al., 2004); and $13.60 \mathrm{~mm}$ and 15.80 $\mathrm{mm}$ (Mahto \& Omar). We found differences in the mean values of AP diameter of vertebral body of the studies given above but American and Koreans having greater values than us. According to data, our result $(14.03 \mathrm{~mm})$ was similar to Indian and Mexico populations. Moreover, transverse width of the vertebral body was measured in between $22.6 \mathrm{~mm}$ and $28.6 \mathrm{~mm}$ in American males, and in American females, whereas the same measurement was between $20.9 \mathrm{~mm}$ and $26.9 \mathrm{~mm}$ respectively ranged from $\mathrm{C} 3$ to $\mathrm{C} 7$ levels (Kwon et al.). The corresponding value was $22.7 \mathrm{~mm}$ and $30.4 \mathrm{~mm}$ in Korean males whereas this dimension was found as 20.8 $\mathrm{mm}$ and $27.3 \mathrm{~mm}$ in Korean females at C3-C7 segments (Lee et al., 2012). Additionally, the corresponding value of Mexican population was between $19.17 \mathrm{~mm}$ and $23.44 \mathrm{~mm}$, respectively (Bazaldúa Cruz et al.). In Indians the vertebral body transverse diameter was reported from $22.8 \mathrm{~mm}$ to 26.4 $\mathrm{mm}$ (Mahto \& Omar). A study in Turkish population the vertebral body transverse diameter was reported between 
$16.49 \mathrm{~mm}$ and $20.51 \mathrm{~mm}$ (Yilmazlar et al.,2003). In present study, the vertebral body transverse diameter was found as $24.45 \mathrm{~mm}$. The vertebral body height reported by Lee $\mathrm{et} \mathrm{al}$. was measured between $12.6 \mathrm{~mm}$ and $14.6 \mathrm{~mm}$ in Korean females, whereas the same value was found from $13.3 \mathrm{~mm}$ to $15.2 \mathrm{~mm}$ in Korean males. In a study of Mahto \& Omar, this height was found between $8.1 \mathrm{~mm}$ and $11.3 \mathrm{~mm}$ (Mahto \& Omar). It can be said that the differences between our findings and the studies given above may be caused by race, genetic and regional factors.

The morphometry of the cervical vertebrae pedicle is used in surgery of the transpedicular fixation to determine the size (length or diameter) of screw. The lamina dimensions which contribute to cervical spine stability, provide important knowledge in cervical laminoplasty for resection of tumors and in ossification of the posterior longitudinal ligament (Bazaldúa Cruz et al.; Prabavathy et $a l$. .). In Mexican population, pedicle length and width values of cervical vertebrae were found between $3.80 \mathrm{~mm}$ and 5.27 $\mathrm{mm}$; and $4.47 \mathrm{~mm}$ and $5.14 \mathrm{~mm}$, respectively (Bazaldúa Cruz et al.). In a study of Prabavathy et al's the pedicle length and width was ranged from $4.46 \mathrm{~mm}$ to $6.96 \mathrm{~mm}$; from 4.40 $\mathrm{mm}$ and $5.80 \mathrm{~mm}$ in Indian population (Prabavathy et al.). Also, lamina height and width dimensions of cervical vertebrae were between 11.27 and $14.31 \mathrm{~mm}$; and $13.92 \mathrm{~mm}$ and $15.59 \mathrm{~mm}$ in Mexico population, respectively (Bazaldúa Cruz et al.). In Indians, the lamina heigth was found between $8.20 \mathrm{~mm}$ and $13.52 \mathrm{~mm}$ (Prabavathy et al.). We found some different findings compared to the above studies in pedicle length (R:5.65 $\pm 1.91 \mathrm{~mm}, \mathrm{~L}: 5.65 \pm 1.76 \mathrm{~mm}$ ), pedicle width (R:3.72 mm, L:3.61 mm), lamina height (R:9.87 mm, L:9.86 $\mathrm{mm})$ and lamina width (R:13.41 $\mathrm{mm}, \mathrm{L}: 13.49 \mathrm{~mm})$ measurements.

The spinous process play a role in screw placement in traumatic and degenerative lesions (Rao et al.). Articular process transmits the compressive forces on the cervical vertebrae. One of the cervical stabilization methods is transpedicular fixation and the other is the transfacet fixation. Transfacet fixation has a minimal risk of nerve root injury. So, it is prefered an alternative method to transpedicular fixation. Moreover, the size adaptation of the superior-inferior articular facets is important due to articular luxation (Bazaldúa Cruz et al.). Also, during wiring or screw the variations of measurement in both side is critical point. Rao et al. reported that there were no significant difference in measurements of the superior articular process and inferior articular process in right and left sides. In contrary, we found bilateral symmetry as well as Indians. Congenital or degenerative narrowing of cervical canal is an significant risk factor for spinal canal stenosis, myelopathy, spinal cord injury. Therefore, the many factors play a important role in morphometry of vertebral foramen as similarly the other sections of the cervical vertebrae. Also, transverse diameter was found larger than anteroposterior diameter similiar to our data (Karakas, et al., 2007; Desdicioglu et al.).

In summary, when comparing our findings with the literature, we found that some differences between American, Indian, Korean and Turkish population's data. We consider that these discrepancies could be a result of such factors like race, genetic factors, cervical vertebrae pathologies, and regional variations. Knowledge of cervical vertebrae anatomy will provide crucial information for neurosurgeons, radiologist or clinicians and will help surgeons to achieve greater success in cervical operations and they can be used as reference values for evaluating pathologic changes and determine the significance of the anatomic structures in cervical region. Therefore, the observations presented in this study have defined anatomic parameters that need to be taken into consideration for evaluate cervical vertebrae problems and guidelines for determine the reference values.

POLAT, S.; GÖKER, P.; YÜCEL, A. H. \& BOZKIR, M. G. Estudio morfométrico de vértebras cervicales secas. Int. J. Morphol., 37(3):845-851, 2019.

RESUMEN: El objetivo de este estudio fue enfatizar la importancia clínica de la morfometría y los parámetros quirúrgicos de las vértebras cervicales. El presente estudio se realizó en noventa y seis vértebras cervicales secas adultas (C3-C7) de sexo desconocido de la población turca. Las diversas dimensiones de las vértebras cervicales (C3 a C7) se midieron utilizando un calibrador digital con una precisión de $0,01 \mathrm{~mm}$. Se determinaron parámetros lineales incluyendo ancho anteroposterior del cuerpo vertebral $(14,03 \mathrm{~mm})$, ancho transversal del cuerpo vertebral $(24,45 \mathrm{~mm})$; altura del cuerpo vertebral (10,64 mm); longitud del pedículo (R: $5.65 \pm 1,91 \mathrm{~mm}, \mathrm{~L}: 5.65 \pm 1,76 \mathrm{~mm}$ ); ancho del pedículo (R: 3,72 mm, L: 3,61 mm); altura de la lámina (R: 9,87 mm, L: 9,86 mm); longitud transversal de la lámina (R: 13,41 mm, L: 13,49 mm); Diámetro anteroposterior del proceso articular superior (R: 7,26 mm, L: 7,46 mm); Diámetro transversal del proceso articular superior (R: 9,87 mm, L: 9,58 $\mathrm{mm}$ ); Altura articular superior del proceso (R: 16,41 mm, L: $16,08 \mathrm{~mm}$ ); Diámetro anteroposterior del proceso articular inferior (R: 7,67 mm, L: 7,44 mm); Diámetro transversal del proceso articular inferior (R: 10,32 mm, L: 10,09 mm); Altura del proceso articular inferior (R: $12,72 \mathrm{~mm}, \mathrm{~L}: 12,67 \mathrm{~mm}$ ); longitud del proceso espinoso (17,91 $\mathrm{mm})$; ancho del proceso uncinado (R: 4,37 mm, L: 3,78 mm); altura de proceso uncinado (R: 4,58 $\mathrm{mm}, \mathrm{L}: 3,93 \mathrm{~mm}$ ); longitud del proceso uncinado (R: 9,28 mm, L: 9,12 mm); Ancho anteroposterior del foramen vertebral $(13,85$ $\mathrm{mm})$; Diámetro transverso del foramen vertebral $(20,88 \mathrm{~mm})$; Ancho anteroposterior del foramen transverso (R: 4,23 mm, L: 4,28 mm); Diámetro transverso del foramen transverso ( $\mathrm{R}: 4,78$ $\mathrm{mm}, \mathrm{L}: 4,95 \mathrm{~mm}$ ). Además, la distancia del vértice del proceso uncinado al foramen transverso (R: 2,91 mm, L: $2,70 \mathrm{~mm}$ ) y la 
distancia del vértice del proceso uncinado al foramen intervertebral (R: 5,77 mm, L: 5,66 mm) Se encontraron diferencias significativas entre los dos lados, en el ancho y la altura del proceso uncinado, y la distancia entre el proceso uncinado y el foramen transverso. Las mediciones actuales sugieren que los parámetros relevantes de las vértebras cervicales se pueden usar como referencia y punto de referencia anatómicos para evaluar los cambios patológicos y minimizar las complicaciones en la columna cervical.

PALABRAS CLAVE: Vértebras cervicales; Vértebras de huesos secos; Antropometría.

\section{REFERENCES}

Abuzayed, B.; Tutunculer, B.; Kucukyuruk, B. \& Tuzgen, S. Anatomic basis of anterior and posterior instrumentation of the spine: morphometric study. Surg. Radiol. Anat., 32(1):75-85, 2010.

Ananthi, V.; Umarani, S. \& Muniappan, V. An osteological study on morphometry of foramen transversarium of sub axial vertebrae and its variations. Int. J. Anat. Res., 7(1.1):6040-4, 2019.

Aydınlıglu, A.; Kavaklı, A.; Yes silyurt, H.; Erdem, S. \& Eroglu, C. Foramen transversarium bipartita. Van Tip Dergisi, 8 (4):110-2, 2001.

Bazaldúa Cruz, J. J.; González Larios, A.; Gómez Sánchez, A.; Villarreal Silva, E. E.; Velázquez Gauna, S. E.; Sánchez Uresti, A. S.; ElizondoOmaña, R. E. \& Guzmán López, S. Morphometric study of cervical vertebrae C3-C7 in a population from Northeastern Mexico. Int. J. Morphol., 29(2):325-30, 2011.

Bozbuga, M.; Oztürk, A.; Ari, Z.; Bayraktar, B.; Sahinoglu, K. \& Gürel, I . Surgical anatomic evaluation of cervical uncinate process for ventral and ventrolateral subaxial decompression. Okajimas Folia Anat. Jpn., 76(4):193-6, 1999.

Dalgic, A.; Okay, O.; Nacar, O.; Daglioglu, E; Pasaoglu, L. \& Belen, D. Vertebral artery insult at the transverse foramina by gun shot wounds: report of two cases. Turk. Neurosurg., 19(4):413-6, 2009.

Desdicioglu, K; Öztürk, K.; Çizmeci, G. \& Malas, M. Morphometric investigation of anatomic structures of vertebras and clinical evaluation: an anatomical study. SDU Sagllk Bilimleri Dergisi, 8(1):16-20, 2017.

Devaraj, B.; Thangavel, M.; Anand, V. R. R.; Nallan, R.; Manoranjitham \& Thangavel, M. Morphometric analysis of typical cervical vertebral pedicle - An osteological study. Int. J. Orthop. Sci., 3(4):704-8, 2017.

Drake, R. L.; Vogl, W. \& Mitchell, A. W. M. Gray's Anatomy for Students. 2nd ed. London, Churchill Livingstone/Elsevier, 2010. pp.71-3.

Gosavi, S. N. \& Vatsalaswamy, P. Morphometric study of the atlas vertebra using manual method. Malays. Orthop. J., 6(3):18-20, 2012

Gujar, S. M.; Oza, S. G. \& Shekhawat, J. P. A study of accessory foramen transversarium in dry cervical vertebrae and its clinical implications. Natl. J. Integr. Res. Med., 6(6):27-30, 2015.

Gupta, S.; Patel, Z. \& Gautam, RS. Morphological study of accessory foramen transversarium in dried cervical vertebrae in human being. Int. J. Anat. Res., 5(2):3791-5, 2017.

Karakas, P. \& Bozkir, M. G. Reference values for radiologic evaluation of cervical canal, vertebral body, and Torg-Pavlov Ratio. Neurosurg $Q$., 17(4):291-3, 2007.

Kocabiyik, N.; Ercikti, N. \& Tunali, S. Morphometric analysis of the uncinate processes of the cervical vertebrae. Folia Morphol. (Warsz), 76(3):440-5, 2017.

Kwon, B. K.; Song, F.; Morrison, W. B.; Grauer, J. N.; Beiner, J. M.; Vaccaro, A. R.; Hilibrand, A. S. \& Alberd, T. J. Morphologic evaluation of cervical spine anatomy with computed tomography: anterior cervical plate fixation considerations. J. Spinal Disord. Tech., 17(2):102-7, 2004.
Lee, T. H.; Kim, S. J. \& Chung, I. H. Morphometrical study of uncinate processes and vertebral body of cervical spine. J. Korean Neurosurg. Soc., 51(5):247-52, 2012.

Lu, J.; Ebraheim, N. A.; Yang, H.; Skie, M. \& Yeasting, R. A. Cervical uncinate process: an anatomic study for anterior decompression of the cervical spine. Surg. Radiol. Anat., 20(4):249-52, 1998.

Mahto, A. K. \& Omar, S. Clinico-anatomical approach for instrumentation of the cervical spine: a morphometric study on typical cervical vertebrae. Int. J. Sci. Study, 3(4):143-5, 2015.

Molinet Guerra, M.; Robles Fuentes, P. \& Roa, I. Anatomical variations of the foramen transversarium in cervical vertebrae. Int. J. Morphol., 35(2):719-22, 2017.

Murlimanju, B. V.; Prabhu, L. V.; Shilpa, K.; Rai, R.; Dhananjaya, K. V. \& Jiji, P. J. Accessory transverse foramina in the cervical spine: incidence, embryological basis, morphology and surgical importance. Turk. Neurosurg., 21(3):384-7, 2011.

Park, M. S.; Moon, S. H.; Kim, T. H.; Oh, J. K.; Jung, J. K.; Kim, H. J. \& Riew, K. D. Surgical anatomy of the uncinate process and transverse foramen determined by computed tomography. Global Spine J., 5(5):583-90, 2015.

Prabavathy, G.; Philip, X. C.; Arthi, G. \& Sadeesh, T. Morphometric study of cervical vertebrae C3-C7 in South Indian population -A clinicoanatomical approach. Ital. J. Anat. Embryol., 122(1):49-57, 2017.

Rao, E. V. K.; Rao, B. S. \& Vinila, B. H. S. Morphometric analysis of typical cervical vertebrae and their clinical implications: a cross sectional study. Int. J. Anat. Res., 4(4):2988-92, 2016.

Sangari, S. K.; Dossous, P. M.; Heineman, T. \& Mtui, E. P. Dimensions and anatomical variants of the foramen transversarium of typical cervical vertebrae. Anat. Res. Int., 2015:391823, 2015.

Sengül, G. \& Kadioglu, H. H. Morphometric Anatomy of the Atlas and Axis Vertebrae. Turk. Neurosurg., 16(2):69-76, 2006.

Tubbs, R. S.; Rompala, O. J.; Verma, K.; Mortazavi, M. M.; Benninger, B.; Loukas, M. \& Chambers, M. R. Analysis of the uncinate processes of the cervical spine: an anatomical study. J. Neurosurg. Spine, 16(4):4027, 2012.

Yesender, M.; Devadas, P.; Saritha, S. \& Vinila, B. H. S. Study on the anatomical variations and morphometry of foramen transversaria of the subaxial cervical vertebrae. Int. J. Anat. Res., 5(2.1):3708-12, 2017.

Yılmazlar, S.; Kocaeli, H.; Uz, A. \& Tekdemir, I. Clinical importance of ligamentous and osseous structures in the cervical uncovertebral foraminal region. Clin. Anat., 16(5):404-10, 2003.

\section{Corresponding author: \\ Dr. Sema Polat}

Cukurova University Faculty of Medicine

Department of Anatomy

Adana

TURKEY

\section{E-mail:sozandac@cu.edu.tr}

Received: 19-11-2018

Accepted: 01-02-2019 